\title{
An Interpretation of Paleomagnetic Results from Cretaceous Granites in South Korea
}

\author{
Haruaki Iтo and Katsuyasu ToKIEDA \\ Department of Physics, Shimane University, Matsue, Japan
}

(Received February 10, 1978)

\begin{abstract}
The mean virtual pole position for the Cretaceous granites in South Korea is close to the present geographic pole and is consistent with that for Cretaceous, Pliocene and Pleistocene volcanic rocks from the same region. It also accords with pole positions obtained from Chinese, Siberian and European Cretaceous rocks. From the paleomagnetic data for the granites and volcanic rocks of the Cretaceous, it is concluded that the South Korean land mass has not been subjected to sufficient local tectonic movements to generate a change in the direction of primary magnetic vectors of the granites or of the volcanic rocks since the Cretaceous. This means that although some tectonic movement has taken place in South Korea since the Cretaceous, the movement brought about only vertical block displacements with no significant tilting or rotational movements. It also suggests that the virtual geomagnetic pole for the Cretaceous rocks in South Korea provides a valid Cretaceous virtual pole position for the Eurasian land mass.
\end{abstract}

\section{Introduction}

The eastern part of USSR, China, Korea and Japan have been in a region of compression in the elastic stress field of the earth as proposed by WILSON (1965). The Japanese Islands lie in a particularly complicated mobile belt (SUGIMURA and UYEDA, 1973). In order to reveal such complicated past movements of the Japanese Islands using paleomagnetic techniques, it is necessary to detect a stationary reference point in or near the Japanese Islands. The eastern part of USSR, China and the Korean peninsula may be the most suitable area to seek such a point for paleomagnetic investigations on the Japanese Islands, because remanent magnetic vectors of Japanese Cretaceous rocks deviate considerably from the present geomagnetic field direction (NAGATA et al., 1959; SASAJIma et al., 1968; KAWAi et al., 1971; Domen, 1971).

The South Korean land mass consists of Precambrian granite gneisses and Mesozoic granites according to the Isotope Ages and Geological Map of Korea compiled by the Geological Survey of Korea (1972). The existence of Precambrian rocks in 
this area suggests that the area may have remained stable for long time. Granites of Paleozoic age are rarely found in South Korea.

The paleomagnetic investigations on the Korean rocks are only a few. The paleomagnetic results from volcanic rocks have been only reported by КIM (1964) and KiEnZLE and Scharon (1966). Therefore, we collected samples of dated granitic rocks in South Korea. In this paper we will describe some paleomagnetic interpretations on Cretaceous granites with due consideration of the paleomagnetic data of the volcanic rocks.

\section{Isotope Ages and Sampling}

Sampling localities for paleomagnetism are listed in Table 1, together with the K-Ar ages of rocks sampled (Geological Survey of Korea, 1972). Masanite in Table 1 is a general name given to rocks including granodiorite, adamellite and some tonalite (KIM and KIM, 1963). The K-Ar age of Masanite at Masan is 84.4 m.y. However, hand samples were taken from the other Masanite body exposed in the northeast of Masan. Only the samples from Chungju (site 5) were collected at the same site at which samples for age determination were taken. All of samples collected belong to the Cretaceous age as seen obviously in Table 1.

One hundred twenty-eight oriented hand samples have been collected from 13 widely spaced sites of the Cretaceous granites in South Korea. We collected samples from two or three sites within one rock body and took more than four samples at each site. This is to examine whether a significant paleomagnetic difference exists within one rock body or not. Then two or more core samples were drilled from each hand sample by using a diamond core drill machine in the laboratory.

\section{Measurements}

The natural remanent magnetization (NRM) of core samples were measured with a spinner magnetometer and an astatic magnetometer. After the NRM measurements were made, a pilot core sample at each sampling site was progressively demagnetized in the alternating field up to 500 Oe maximum peak value. The optimum peak field was 100 Oe for core samples in this case. Systematic magnetic cleaning by the alternating field technique was applied to all core samples investigated using a two-axis tumbler and a three-layer Mumetal shield to cancel the effect of the earth's field. Initial NRM directions of these samples were somewhat scattered. After demagnetization to 100 Oe, however, the NRM directions from nine sites were tightly grouped, which suggests a primary direction of the remanent magnetization. The NRMs from four sites unstable after alternating field treatment of 100 Oe. Subsequently, two sites belonging to one rock body are taken as a locality.

The site-mean directions of NRM after demagnetization of 100 Oe are shown in 


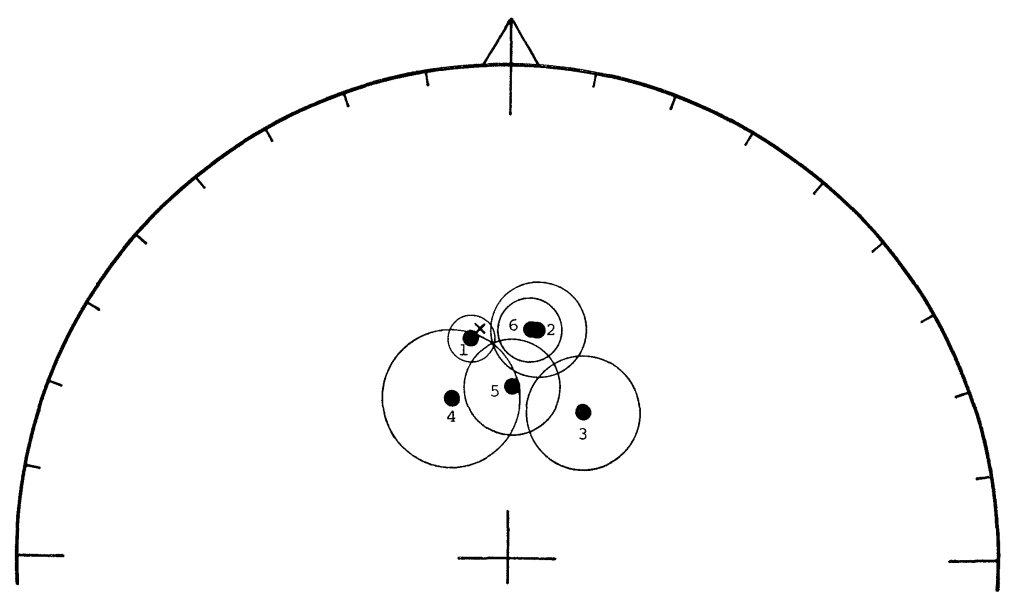

Fig. 1. Site-mean directions of the NRM after demagnetization of 100 Oe. Closed circles are lower hemisphere projections on equal area net. Circles of $95 \%$ confidence are drawn around each site-mean direction. Cross mark represents the present field direction at Daegu.

Fig. 1 and results of measurements are also summarized in Table 1. All the samples with the stable remanent magnetization are normally magnetized. A mean direction of the NRM for all sampling sites is $3.5^{\circ}$ in declination and $57.3^{\circ}$ in inclination. The present field direction at Daegu $\left(35^{\circ} 52^{\prime} \mathrm{N}, 128^{\circ} 35^{\prime} \mathrm{E}\right)$ where we adopted here as a standard point is roughly $6.5^{\circ} \mathrm{W}$ and $51^{\circ}$.

The mean direction of the NRM of Cretaceous volcanic rocks obtained by KIENZLE and SCHARON (1966) is $19.5^{\circ}$ in declination and $53.3^{\circ}$ in inclination. The difference in direction of the NRM between the granites and volcanic rocks is about $16^{\circ}$ and $4^{\circ}$ respectively. However, this difference may not be so important, because the virtual geomagnetic poles for the two rocks lie near the geographic and magnetic poles. The mean NRM direction obtained from the Pliocene and Pleistocene volcanic rocks in South Korea is $19.8^{\circ}$ in declination and 50.0 in inclination (KIM, 1964). All of the site-mean directions of NRM of the Cretaceous volcanic rocks (KIENZLE and Scharon, 1966) and Pliocene and Pleistocene volcanic rocks (KIM, 1964) are shown in Fig. 2.

Intensities of the NRM after demagnetization of 100 Oe are also listed in Table 1. Although Masanite samples collected from near Masan have an intensity of $1.52 \times$ $10^{-4} \mathrm{emu} / \mathrm{cc}$, the intensities of biotite granites from the other sites are of the order of $10^{-5}$ to $10^{-6} \mathrm{emu} / \mathrm{cc}$.

Curie point determinations demonstrate that the dominant magnetic phase is magnetite in the stable samples investigated. Three examples of thermomagnetic curves for the stable samples are shown in Fig. 3. Some of the unstable samples showed thermomagnetic curves suggesting coexistence of two titaniferous magnetite 


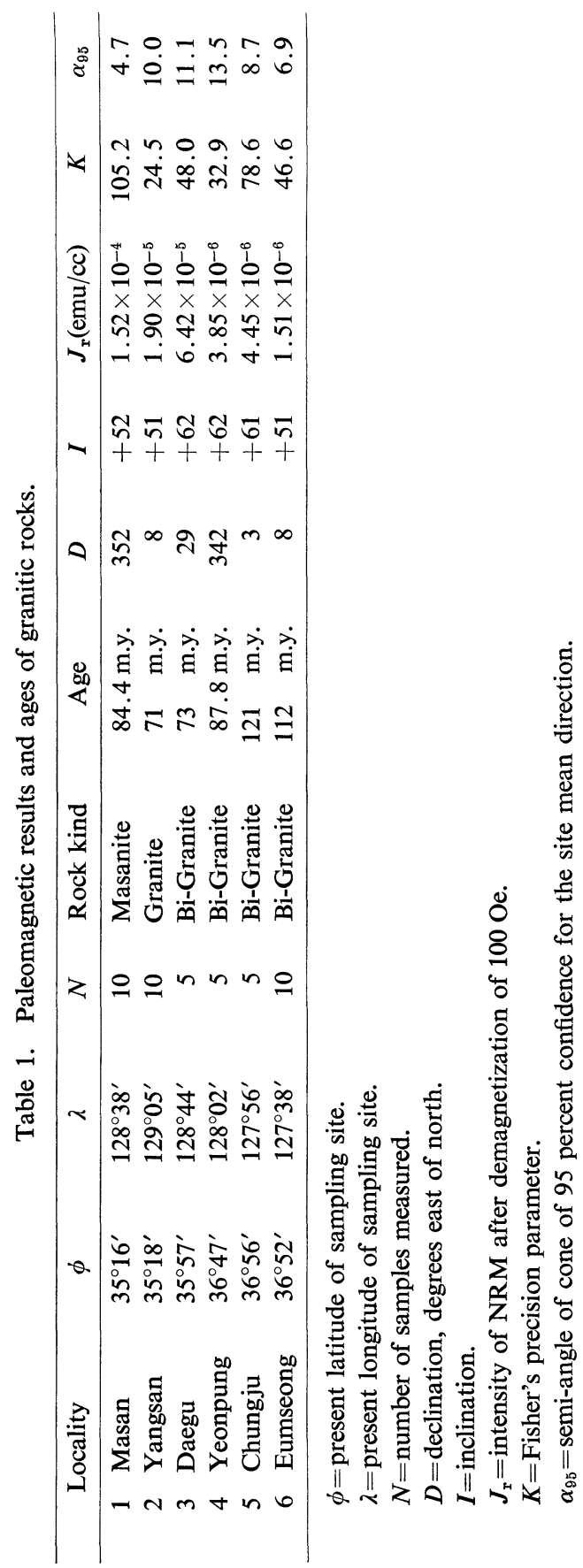




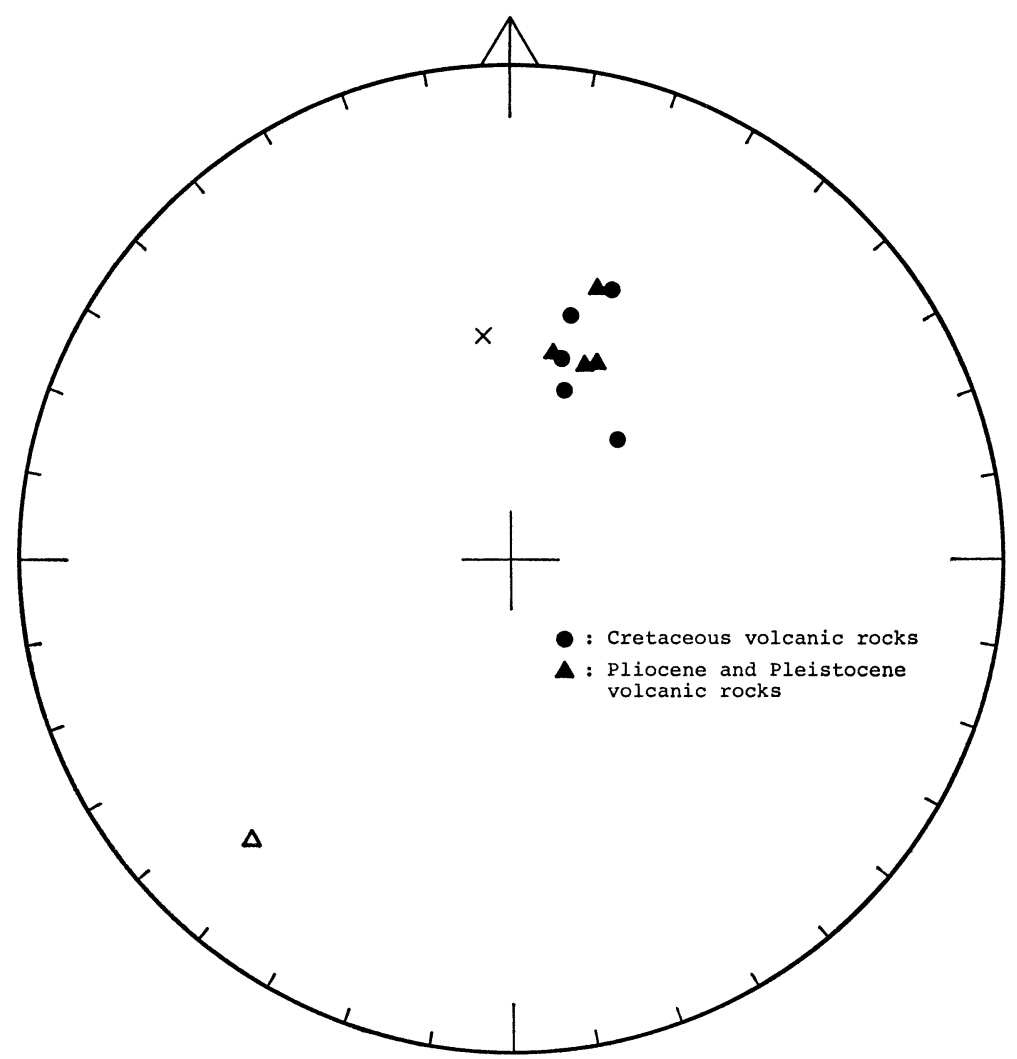

Fig. 2. Site-mean directions of the NRM obtained from Cretaceous volcanic rocks (closed circles) by KIENZLe and SCHARON (1966) and Pliocene and Pleistocene volcanic rocks (closed and open triangles) by Кiм (1964). Closed circles and triangles are lower hemisphere projections and open triangle is upper hemisphere projection on equal area net. Cross mark represents the present field direction at Daegu.

phases.

\section{Virtual Geomagnetic Poles}

According to presently available paleomagnetic data (McElHinny, 1973), the average Cretaceous paleomagnetic pole for continental lands in the Northern Hemisphere seems to be located nearly around Wrangel Island $\left(71^{\circ} \mathrm{N}, 180^{\circ} \mathrm{E}\right)$. It is generally considered that this position of paleomagnetic pole which is clearly different from the geographic pole represents definite relative motion of the pole and the continental land mass investigated. The virtual poles for the Sikhote Alin and Kolyma block in Siberia deviate markedly from the averaged virtual pole position of the Cre- 


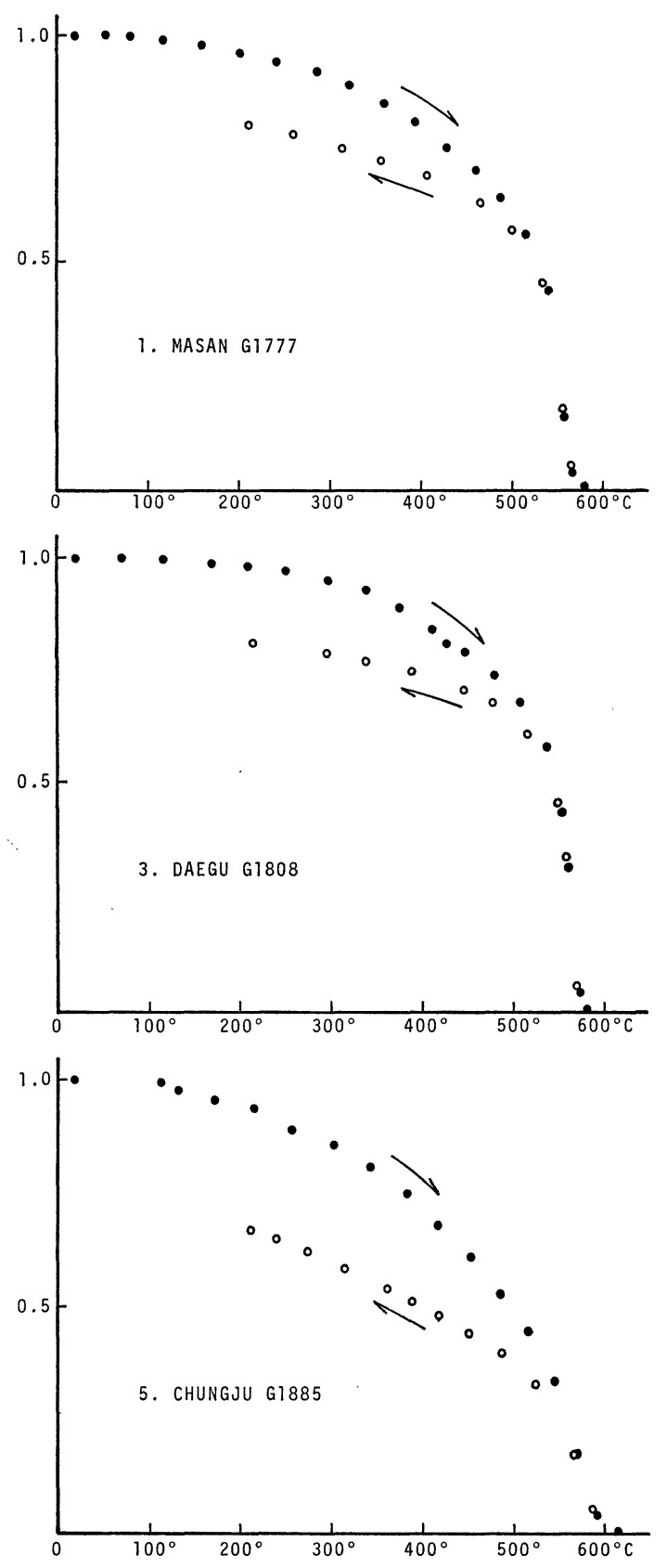

Fig. 3. Thermomagnetic curves of typical stable samples. 


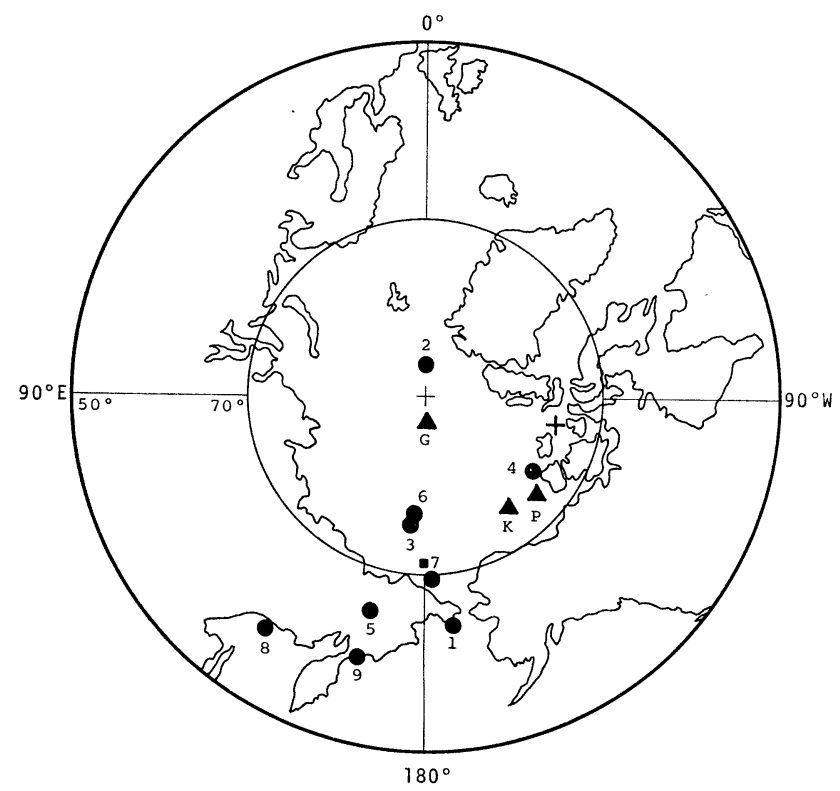

Fig. 4. Cretaceous virtual geomagnetic poles from continental lands in the Northern Hemisphere. Closed triangles are South Korean data. G, Granitic rock (present study); K, Cretaceous volcanic rock (KIEnzle and Scharon, 1966); P, Pliocene and Pleistocene volcanic rocks (KIM, 1964). Closed circles are data from the other continental lands in the Northern Hemisphere (McElhinny, 1973). 1, North America; 2, W. Europe; 3, S. Europe (Spain, Portugal); 4, S. Europe (Pannonia); 5, Russian platform; 6, Siberian platform; 7, China; 8, Sikhote Alin (Lr); 9, Kolyma block. Closed square is an averaged Cretaceous virtual geomagnetic pole for continental lands in the Northern Hemisphere.

taceous as seen in Fig. 4. As these regions were situated in the orogenic belts since the Mesozoic time (Hamilton, 1970), this deviation may be due to some regional tectonic movements.

The mean pole position for the Cretaceous granitic rocks of South Korea is very close to the geographic pole. However, the virtual pole for the volcanic rocks obtained by KIENZLE and SCHARON (1966) is rather close to the present magnetic north pole as seen in Table 2 and Fig. 4. This discrepancy between the virtual poles may also be unsubstantial, because values of the polar error $(\mathrm{d} p, \mathrm{~d} m)$ of both rocks are relatively high. It is, however, worthy of note that the virtual pole position for the Cretaceous volcanic rocks are quite similar to that for the Pliocene and Pleistocene volcanic rocks sampled from the same land mass.

From the available paleomagnetic data, it is positively concluded that the virtual geomagnetic pole calculated from the Cretaceous rocks in South Korea gives us a valid mean virtual position for the Eurasian land mass during the Cretaceous. 


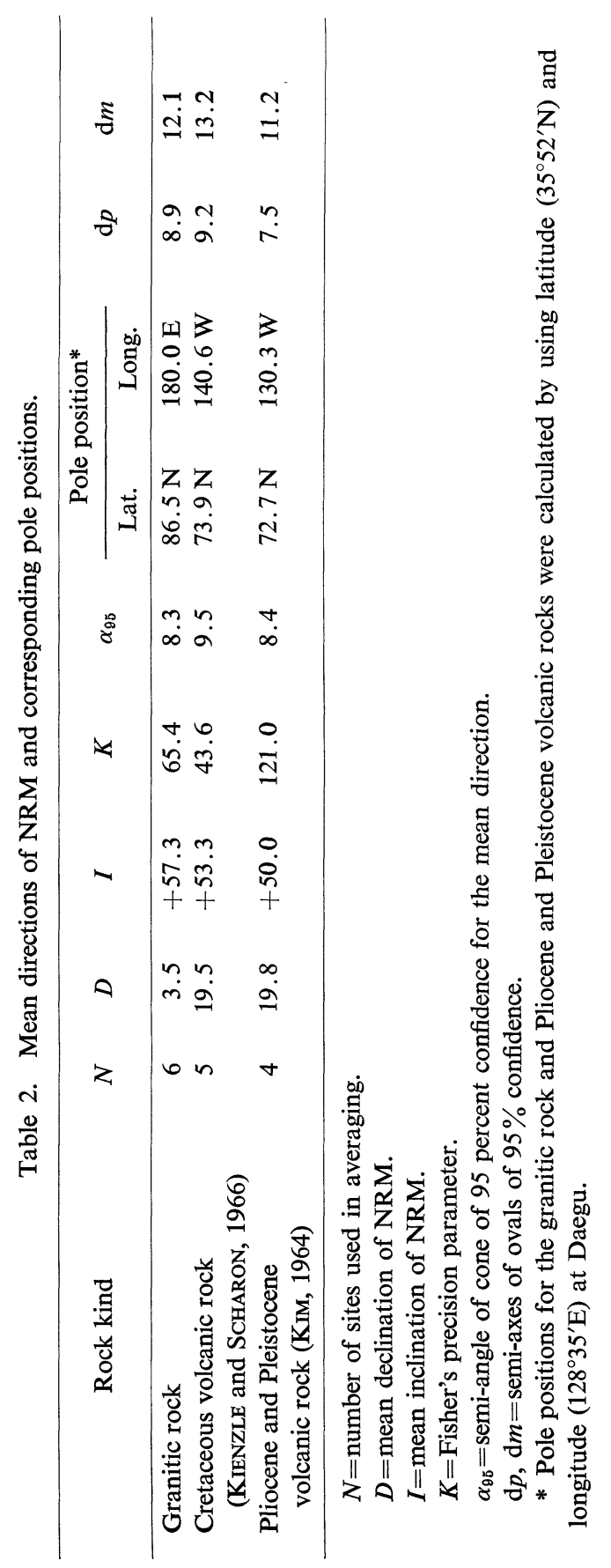




\section{Discussion}

As seen in Fig. 4, the virtual poles for the Cretaceous rocks of South Korea are rather consistent with those for rocks of Western and Southern Europe and Siberian platform, and also appear to be close to the present geographic or magnetic north pole. On the contrary, the virtual poles for the Cretaceous rocks of North America, Russian platform, China, Sikhote Alin region and Kolyma block in the eastern USSR deviate distinctly from the present geographic or magnetic north pole (LEE et al., 1963; McElhinny, 1973).

Assuming that an averaged virtual pole position during the Cretaceous and early Tertiary was located at the Wrangel Island $\left(71^{\circ} \mathrm{N}, 180^{\circ} \mathrm{E}\right)$, the virtual geomagnetic poles for Cretaceous rocks of North America, South Europe, Russian platform, Siberian platform and China are rather close to the averaged virtual pole. The virtual poles from Korean rocks lie in a limited area surrounded by three points of the geographic, magnetic and averaged virtual poles. This suggests that the amount of polar movement since the late Cretaceous was small and negligible.

On the other hand, the paleomagnetic data of the Japanese Cretaceous and early Tertiary rocks indicate more complex and intense deformations of the Japanese Islands (NAGATA et al., 1959; SASAJIMA et al., 1968; KAWAI et al., 1971; DomEN, 1971; YASKAWA, 1973; Ito and ToKieda, 1974). It seems to be due to the fact that the Japanese Islands have been situated in the intense mobile belts since the Cretaceous.

If the South Korean land mass has been deformed by past tectonic movements as the Japanese Islands, there should be a paleomagnetic record to be found by using the NRM directions of rocks. However, it should be reminded that neither vertical block displacement with no distinct tilting or rotational movement nor movement of a land mass parallel to lines of latitude can be detected by paleomagnetic methods, because the direction of remanent magnetic vector of rocks is not affected by such a movement.

As described above, the paleomagnetic data from the South Korean Cretaceous rocks does not provide us with evidences of visible polar movement or striking tilting deformations of the land mass. Although vertical block movements are paleomagnetically undetermined, it is concluded that the South Korean land mass has been tectonically stable since the Cretaceous.

We would like to thank Professor M. Fuller at the University of California, Santa Barbara for allowing us to use a spinner magnetometer in his laboratory and for critical reading of the manuscript. This work was done under the Japan-U.S. Cooperative Scientific Programme administered by the Japan Society for the Promotion of Science.

\section{REFERENCES}

Domen, H., Additional data to the paleomagnetic pole positions for the Cretaceous rocks in Yamaguchi Prefecture, West Japan, Bull. Fac. Edu. Yamaguchi Univ., 20, 21-23, 1971. 
Geological Survey of Korea, Isotope Ages and Geological Map of Korea, 1972.

Hamilton, W., The Uralides and the motion of the Russian and Siberian platform, Geol. Soc. Am. Bull., 81, 2553-2576, 1970.

Ito, H. and K. ToKIEDA, Tilting of Hokkaido Island and Kitakami Mountains deduced from the NRM of Cretaceous granitic rocks, Rock Mag. Paleogeophys., 2, 54-58, 1974.

KaWAI, N., T. NakaJIMA, and K. Hirooka, The evolution of the Island Arc of Japan and the formation of granites in the Circum-Pacific belt, J. Geomag. Geoelectr., 23, 267-293, 1971.

Kienzle, J. and L. Scharon, Paleomagnetic comparison of Cretaceous rocks from South Korea and late Paleozoic and Mesozoic rocks of Japan, J. Geomag. Geoelectr., 18, 413-416, 1966.

KIM, B. K., The study of remanent magnetism for basalts in Yeoncheon and Pohang districts in Korea, J. Geol. Soc. Korea, 1, 50-56, 1964 (in Korean with English abstract).

KIM, J. H. and J. T. KIM, Explanatory text of the Geological Map of Korea, Masan sheet, Scale 1: 50000, Geol. Surv. Korea, 1963 (in Korean with English abstract).

Lee, J. T., H. M. Lee, H. S. LiU, C. Lie, and S. S. YeE, Preliminary results of paleomagnetic study of some Cenozoic and Mesozoic red beds, Southern China, Acta Geologica Sinica, 43, 241-245, 1963 (in Chinese with English abstract).

McElhinny, M. W., Palaeomagnetism and Plate Tectonics, pp. 201-219, Cambridge Univ. Press, London, 1973.

Nagata, T., S. Akimoto, Y. Shimizu, K. Kobayashi, and H. Kuno, Palaeomagnetic studies on Tertiary and Cretaceous rocks in Japan, Proc. Jpn. Acad., 35, 378-383, 1959.

Sasajima, S., J. Nishida, and M. ShimadA, Paleomagnetic evidence of a drift of the Japanese Main Island during the Paleogene period, Earth Planet. Sci. Lett., 5, 135-141, 1968.

Sugimura, A. and S. UYeDA, Island Arcs-Japan and Its Environs, pp. 46-76, Elsevier, Amsterdam, 1973.

Wilson, T., A new class of faults and their bearing on continental drift, Nature, 207, 343-347, 1965.

YaSkAWA, K., Drift of Southwest Japan relative to South Korea since late Mesozoic-A paleomagnetic approach to the origin of the Japan Sea, Rock Mag. Paleogeophys., 1, 77-82, 1973. 